\title{
Editorial
}

\section{Is international law the enemy of national democracy?}

A former dictator is arrested in another State with a view to trial in a third for crimes against international law. The successor government, democratically elected, protests that to carry through this procedure will undermine the country's still fragile democracy. In another region of the world, internal oppression by a regime of scant democratic legitimacy is visited, in the name of international humanitarian law, by military attack by an alliance of other States over the objection of opponents of the regime, who fear its reinforcement rather than its internal overthrow in favour of a more genuine democracy. These contemporary situations have added dimensions of drama and tragedy to the question posed in the title, but it is a question that has, for some time, presented difficult and challenging issues in the broad context of peaceful and productive human relations. That is the context in which we shall examine it, hoping that more general insights about the relationship between national democracy and international law may also help to inform judgement on these cases on the outer margins of human behaviour.

The argument for a positive answer to our question is usually put as follows. International law is formed in an inherently non-democratic way, either by conclaves of treaty negotiators collectively responsible to no representative body or by the evolution of 'customary' legal rules, through State practice grounded in a sense of legal obligation - a process leaving even less scope for open 'democratic' argument. As the range of international legal obligations steadily broadens, and their content increasingly addresses behaviour occurring within the physical confines of the State, as opposed to issues arising in inter-State or transnational contacts and relations, so the power of the executive government, charged with the negotiation of these treaties and responsible for the conduct that represents State practice, steadily grows at the expense of national legislatures and other democratic instances. The decision-making capacity of these governments is increasingly pre-empted by international obligations in whose formulation they have been able to play little if any part. The process is dramatically accelerated and reinforced in those areas where a treaty has created a supranational governmental capacity, as in organizations like the International Maritime Organization, the World Trade Organization, or - last but hardly least - the European Union. Such a capacity will ordinarily involve a continuing process of elaboration of binding decisions, whether in the form of general rules, specific orders, or determinations of disputes, over which national democratic organs will be able to exercise little if any control. If advertisements in airports across the EU are to be believed, this is just what has happened to cause the demise of duty-free shopping by 
travellers in the EU; national leaders, having (short-sightedly?) decreed its abolition a few years ago, now find themselves prevented, by the supranational status of their decision, from responding to the democratic upsurge in favour of the retention of this economic sector.

The relationship between international law and national legislation happens to be an area in which rather clear lines can be drawn among national constitutions by reference to their treatment of international legal obligations. A close look at the matter discloses, however, that these differences do not provide a way around the argument, by identifying the approach which best reconciles international legal obligations with democratic imperatives. Some systems, termed 'dualist', try to maintain a clear separation between the two kinds of law. In United Kingdom law, treaty-making is a matter purely for the executive, which can place the State under a binding international obligation without consulting Parliament. Such an obligation, however, can have no internal legal effects inconsistent with existing legal rights and duties, so that if such effects are necessary, they must be produced by ordinary legislation. In practice, therefore, the executive does not ratify unless it is assured, at least in general terms, of legislative support where this is needed. Other, 'monist', jurisdictions recognize that an appropriately designed treaty may produce direct legal effects in internal law and enjoy a rank in the legal hierarchy equivalent, or superior, to domestic legislation. Such jurisdictions, however, tend to demand that treaties receive legislative approval as part of the process of ratification, so that they do not bind the State in international law unless and until they have been accepted into domestic law. Both types of system, therefore, seek to ensure the democratic acceptance of international legal obligations into the national legal order.

There is plenty of room for argument as to which kind of system may, in practice, offer better opportunities for national democratic control over the international law-making process although there is no obvious way of making empirically-grounded generalizations that might resolve it. Diverse national structures and traditions of legislation, shifting political contingencies, and varying degrees of executive commitment to treaty accession, combine to make comparative measurement an impossible task even in relation to simple substantive treaties. Comparison may actually be easier when structures of international governance are set up. Here, the dualist approach tends to be completely subverted, and the monist approach, in its democratic aspects, substantially weakened, by the need to find efficient and reliable means whereby decisions within such structures may be given full effect within the legal systems of the member States. Since those members will ordinarily be legally committed, in advance, to the implementation of such decisions, the question of how democratic is the mode of their preparation presents itself with even greater force. At the same time, the existence of a decision-making structure in which the supranational elements are common to all State participants gives general and comparative observations a lot more plausibility.

Within the framework of the European Union, the most advanced and intensively studied example available to us, the balance of those observations has, in recent years, been decidedly negative. The democratic deficit of the EU now has its own vast literature, which draws our attention not only to the inability of national Parliaments to hold their Ministers accountable for decisions taken collectively, and by negotiation, in the Council of Ministers, and to the lack of powers and capacity in the European Parliament to do the job instead, but also to the concealment of the European policy process in a proliferating mass of committees of officials. In addition, in areas like the 'third pillar' of EU activity (justice, defence and foreign affairs), 
where the writ of the European Court of Justice does not automatically run, it is alleged that there has been deliberate insulation of its results from ex post judicial scrutiny.

Without suggesting that these strictures are in any way incorrect or even overstated, one might still ask whether they support a general statement that 'the rule of law on the international plane will tend to favour executive rule domestically', the postulate of a recent symposium at the Hogendorp Centre for European Constitutional Studies in Amsterdam. Let me offer, from a United Kingdom standpoint, some considerations in favour of a more nuanced approach.

In the first place, what is the nature of the national democratic process that is presumed to be impaired, or in the case of international governance, replaced, by processes of international decision-making? The fact that the executive enjoys a direct or indirect popular mandate for the period of its tenure is clearly not by itself enough to assuage demands for democracy in a lawmaking process which the executive dominates; it is the contribution of other organs, like the legislature and its committees, that is really deemed to count for something. Is that contribution necessarily less, or less effective, when the key moment in the decision-making process requires the assent of a number of different States? The complaint of the legislature, in such a case, must be that, whether the constitution is monist or dualist, it is faced at the end of the process with a fait accompli and has had no chance to influence the progression towards it. Yet this is a situation which differs only in degree - if it differs at all - from the routine of domestic legislation. Such legislation does not spring spontaneously from Parliamentary musings on the general good. The ideas that go into it are very largely the executive's and, even if conceived in public - in party manifestos or in the recommendations of public inquiries - they are brought to term in private, normally in intensive consultation, or negotiation, with interested parties, so that by the time they (or rather the changes to the law that will give them effect) are laid before Parliament as legislation, executive room for manoeuvre is closely circumscribed. The job that remains to be done by the legislature is one of acting as the mouthpiece for unsuccessful negotiating positions, articulating broad-brush political opposition, testing for substantive and technical coherence, and eliciting undertakings as to how the law may operate.

In performing these tasks, the legislature does not so much make law as make the executive accountable for its lawmaking. This role, just as important in relation to legislation that results from international negotiation, is naturally enhanced to the extent that the legislature can review the executive's actions and arguments at different stages along the way to the formulation of final proposals. There is no intrinsic reason why the presence of an international element should make it more difficult for a legislature to obtain the information that would enable it to do this. Indeed, the greater formality and higher visibility that normally attach to international than to domestic negotiations may make the task easier. How and why legislatures fail in this is a useful subject for comparative study.

We accept the essentially private nature of development of domestic legislation because we understand that there is a diffuse democratic constraint on the executive - the desire for re-election - which links its self-interest with that of the voting majority, and that in many cases its resources in government may need to be deployed with some tactical freedom in negotiation if that public interest is to prevail for the purpose of regulating and balancing powerful private interests through national or, indeed, international legislation. In commerce, finance, industry and agriculture such interests are self-evidently present. The legislative role 
is, in other words, conceived of against a background of countervailing public and private power. Yet such a balance may not always be present; when we legislate for changes in criminal law or procedure, or in immigration law, countervailing economic interests are notably absent, and even the apparatus of interest group representation may be unusually weak. It is in such fields that the apparatus of legislative procedure, democratically conducted through an assembly in which expression may be given to every type of opinion, even the least popular, may offer the sole constraint on executive opinion and policy. Here, one might argue, the legislature should have the largest part to play in the oversight, at all stages, of the development of the law-making project, and here too may be the greatest danger of legislative exclusion through the joint development of such projects by executives in international negotiation. It seems no accident that the parts of European lawmaking that have been least transparent - the Schengen Treaty and its subsequent incorporation into the EU structure - should have been those concerned with the treatment of a particularly powerless group: third-state nationals seeking entry to the territory of EU states.

The second question to ask is how the increasing legalisation of policy at the international level, through treaty commitments on everything from pollutant emissions to cyber-copyright, modifies the understanding and practice of democracy in different States. What is the role, in that practice, of domestically-generated legal rules? Today, almost everywhere in Europe, democratic politics - a politics responsive to public opinion - accords unquestioned primacy to some legal rules: those contained in the constitution, and accepted as constraining the 'popular will' by reference to broadly accepted and long-standing fundamental values and structures. But at lower levels, the deployment or avoidance of legal rules in the process of framing and implementing policy seems to be a matter of national tradition and taste. In Italy, new legislation may appear each time a new policy problem is perceived or an old one remembered, often with little regard to the content of existing legislation and its implementation (or the lack of it). In the United Kingdom, the traditional posture of the executive has been to avoid legislation altogether, as an undesirable fetter on its discretion, if problems could be resolved without it, and where unavoidable, to confine it to providing the instruments of policy rather than articulating policy itself. To judge by the fears, expressed a few years ago by many European lawyers, of a flood of norms (Normenflut) that would sweep away legal principles on a tide of short-lived, incoherent and technical laws, most European jurisdictions have tended towards the Italian rather than the British practice, but the point we should note is that both contrasting positions operate to minimize the normative constraints imposed by legislation on the content of policy, in the interests of responsiveness to democratic pressure for policy change.

Laws made at the international level, however, cannot be so freely manipulated. By reason of the difficulty of reopening international negotiations, or even of reversing or revising European Union decisions (as duty-free operators learned to their cost), such laws are innately more stable than their national counterparts, and hence much more likely to place a real barrier in the way of response to future changes of popular sentiment. Undoubtedly, therefore, there is antagonism between modern, policy-oriented international law and a concept of democracy that gives primacy, over all else, to what the people want now. But not only does European constitutional practice negate such a concept, so too does the dominant trend in political economy. Not very long ago, it was only third world countries, in need of foreign investment 
or rescheduling of debt, which needed to conduct their economic policy with one or both eyes fixed on the reactions of the international financial community. Today, the strength and agility of private operators in foreign currency and other international financial markets, and the globalization of competition for investment, impose this discipline on all States. Stability, predictability and orderliness in change, are among the prime tenets of that discipline, and we find them expressed in the subjection of the core elements of economic policy, national monetary and fiscal decisions, to a new apparatus of rules and standards. Within the EU's Economic and Monetary Union, monetary decisions have been removed altogether from the national democratic influence, but the global trend to constraining standards may be better exemplified by the EU's stability and growth pact, with its quantification of acceptable policy outcomes, or the United Kingdom's Code of Fiscal Stability (1998), through which the executive has invited Parliament to bind it to the observance of two overriding rules of financial management during its period in office.

Under the influence of globalized financial markets, therefore, we see a deliberate attenuation in the responsiveness of national economic policies to short-term popular pressure or dissatisfaction. This can hardly be characterized as a clandestine operation by executives avid for greater power. The EU changes, in particular, have been effected only after lengthy democratic processes, often including referenda. It rather represents a conscious acceptance of the value of controlling decision-making by predetermined rules or standards, whose stability is ensured by the difficulty of recruiting the consensus needed to change them. The same acceptance underlies the readiness of States to subject an increasing range of their policymaking in other areas to the constraints of international agreements. The nature of the interest in a common solution will vary with the subject-matter, but the impact on domestic politics is the same.

Setting rules and structures for executive decision-making in the medium term may surely be as genuine an expression of democracy as is a system that facilitates changes of policy from day to day. Whether it actually works this way depends on the performance of the legislature, in two ways. First, as we have seen, the legislature needs to find ways of ensuring that the role in approval of international legal obligations, constitutionally reserved to it, is effectively exploited, especially in cases where it provides the only real counterweight to executive power. Second, it needs to understand and adapt to the changes in executive accountability that result from operating within a framework of rules and standards. Courts are not necessarily the only, or the best, guardians of internationally determined standards, even though they are expressed in the form of legal rules. Legislatures need to consider how their own structures and procedures might exploit the sharper criteria for judgement of executive performance that international law can offer.

Democracies that cannot meet this challenge to adapt to international and transnational demands may indeed find themselves one day with enemies of their own making.

\author{
Terence Daintith \\ Professor of Law \\ Institute of Advanced Legal Studies, University of London \\ Senate House, Malet Street, London WC1E 7HU
}

